血清 $\mathrm{LDH}$ 值の変動を示した盲腸原発悪性リンパ腫の 1 例

\author{
大阪市立大学第 1 外科（主任：梅山 馨教授） \\ 八代 正和西脇英樹妙中直之 \\ 藤本泰久奥野匡有梅山馨
}

症例は19歳男性，右側腹部痛および下血を主訴に来院した。右側腹部に手拳大の腯瘤 を触知し，血液検查では，血沈値の亢進と，CRP 陽性を示した，下部消化管造影および 大腸内視鏡検査にて, 回盲部に隆起性病变を認め, 生検およびガリウムシンチなどより, 悪性リンパ腫を筑った。開腹時, 回盲部腫瘤および腹膜への播種性転移を認め, 右半結 腸切除および回腸横行結腸吻合術を行った。術後 2 週間目頃より血清 LDH 值の上昇お よび腹水の眝留を来たし，悪性リンバ腫の増悪が疑われた。化学療法施行後, 急性腎不 全を併発したが, 血清 LDH 值の低下お゙よび腹水の減少を認めた。 以上, 盲腸原発悪性り ンバ䡌の 1 例, 特に, 手術および化学療法の経過中に血清 $\mathrm{LDH}$ 值の変動を示した 1 症例 を経験したので報告した。

卖引用語：盲腸原発悪性リンパ庫, 血清 LDH 值, 化学療法

はじめに

消化管原発悪性リンパ腫,なかでも大腸原発悪性リ ンパ腫の報告は少なく122)，予後は必ずしも良好とはい えない，今回，われわれは，手術および化学療法の経 過中に, 血清 LDH 值の変動を示した盲腸原発悪性リ ンバ腫の1例を経験したので報告する。

$$
\text { 症例 }
$$

患者：19歳男性.

主訴：右側腹部痛および下血。

既往歴，家族歴：特記すべきことなし。

現病歴：昭和63年 8 月下旬上り, 右側腹部鈍痛を自 覚し，9月16日には，血性下浰便を認め内服治療をう けたが，9月30日多量の下血，呕吐がみられたため近 医に入院し，注腸検査および超音波検查にて，腹部腫 瘤が指摘され，10月21日当院へ転院となる。

入院時現症：体格中等度, 栄盖良好, 身長 $172 \mathrm{~cm}$, 体 重82kg. 頸部リンパ節, 腋嵩リンパ節, 単径部リンパ 節などの表在リンバ節は触知せず，眼䀫結膜に貧血を 認めず，眼球結膜黄庭なし，口蓋扁桃腫脹なし，呼吸 音異常なく，心雑音聴取せす。腹部は平坦軟、肝脾腎 は触知せず．右側腹部には軽度の圧痛を伴 $58 \mathrm{~cm} \times 9$ $\mathrm{cm}$ 大の腫瘤を触知した。腫瘤は軽度可動性を有し, 弾

\footnotetext{
1989年12月 30 日受付 1990年 6 月 27 日採用
}

性硬, 辺縁鮮明, 表面平滑であった。

入院時臨床検查成績：血清 LDH $か 5558$ IU 子軽度上 昇. 赤沈值が， $40 \mathrm{~mm} / \mathrm{hr}, 68 \mathrm{~mm} / 2 \mathrm{hr}$ と六進し, CRP が+2で陽性を示した，その他，末梢血には賓血なく，

\section{表 1 入院時臨床検查成綘}

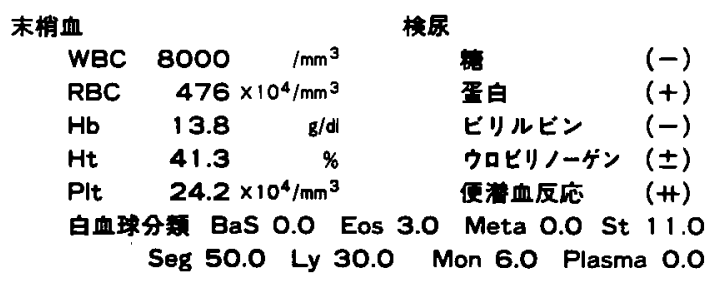

\begin{tabular}{|c|c|c|c|c|c|}
\hline $\begin{array}{l}\text { 学柃查 } \\
\text { TP }\end{array}$ & & & & & \\
\hline TP & 7.1 & $g / d i$ & $\mathrm{Na}$ & 143 & $\mathrm{mEq} / \mathrm{l}$ \\
\hline Alb & 4.1 & $g / d \mid$ & k & 4.2 & $\mathrm{mEq}$ \\
\hline TTT & 0.6 & $u$ & $\mathrm{Cl}$ & 104 & \\
\hline $2 T T$ & 6.2 & $u$ & $\mathrm{Ca}$ & 4.6 & \\
\hline T-Bil & 0.6 & $\mathrm{mg} / \mathrm{dl}$ & & & \\
\hline GOT & 28 & in & M基マーカー & $1-$ & \\
\hline GPT & 27 & U & $\alpha-F P$ & $<5.0$ & \\
\hline ChE & 0.67 & $\Delta p H$ & CEA & 0.7 & \\
\hline FES & 90 & $\mathrm{mg} / \mathrm{d} \sharp$ & CA19-9 & 1 & \\
\hline ALP & 7.8 & KAU & & & \\
\hline$\gamma$-GTP & 6 & $\mathrm{~m} \mu / \mathrm{ml}$ & ATLA & $<16$ & \\
\hline LAP & 15 & $\mathrm{~m} \mu / \mathrm{ml}$ & 赤沈 & 40 & $\mathrm{~mm}$ \\
\hline LDH & 558 & wo & & 68 & $\mathrm{~mm}$ \\
\hline BUN & 8 & $\mathrm{me} / \mathrm{dl}$ & CRP & 2.0 & \\
\hline Cre. & 1.2 & $\mathrm{mg} / \mathrm{dl}$ & & & \\
\hline
\end{tabular}


白血球分画にも異常なし。また，CEAゃCA19-9等の 血清腫瘍マーカー値の上昇も認めなかった（表 1 ）。

腹部単純写真：異常なし.

下部消化管造影：盲腸から上行結腸にかけて，辺縁 鮮明, 粘膜面平滑で, 伸展性のやや不良な陰影欠損を 認めた（図 1 ).

腹部超音波検査所見：盲腸から上行結腸にかけて約 $10 \times 5 \times 8 \mathrm{~cm}$ 大の low-isoechoic な内部不均一ェコー 像を認め,リング状を呈していた.肝脾腫は認めなかっ た.

ガリウムシンチグラム：右側腹部の腫瘤に一致し

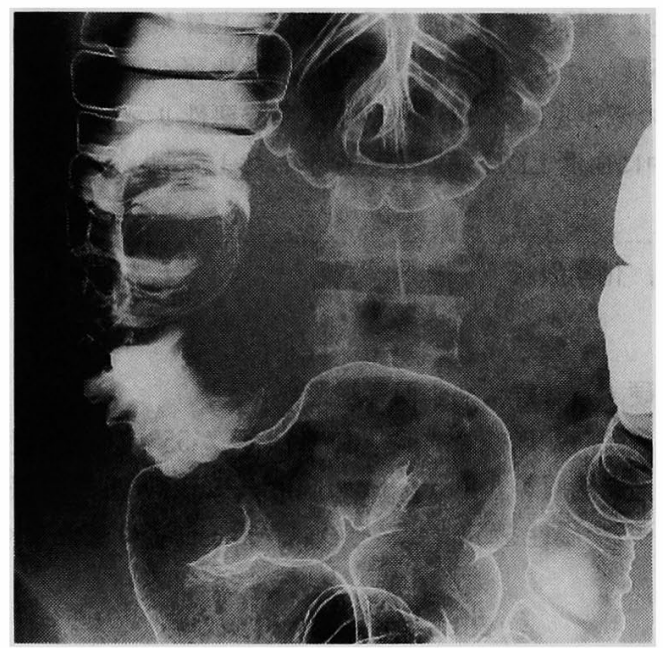

図 1 下部消化管造影：盲腸から上行結腸にかけて陰 影欠損が認められる。

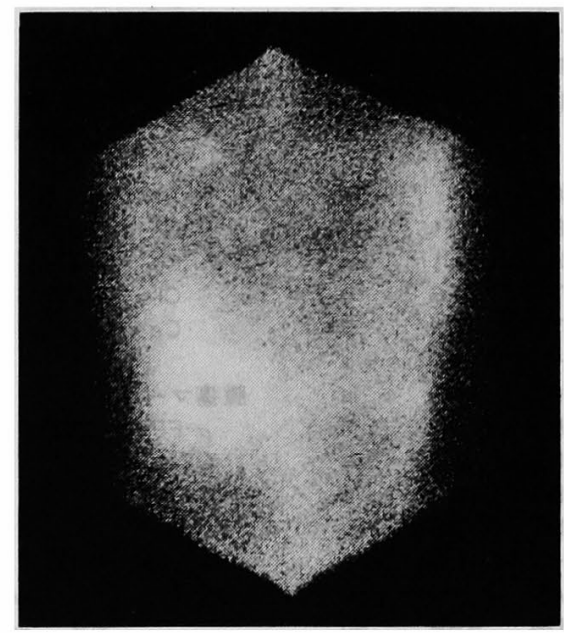

図 2 カリリウムシンチグラム: 右側腹部の腫瘤に一致 して,ガリウムの強い集積が認められる。
て，ガリウムの強い集積を認めた（図 2 ）。

単純 CT 検查：盲腸から上行結腸にかけて, $9 \times 8 \mathrm{~cm}$ 大の soft density mass を認めた。訮脾腫は認めなかっ た (図 3 ).

大腸内視鏡検査所見：盲腸から上行結腸にかけて, 表面やや不整な隆起性病変を認めた。生検所見から, 悪性リンパ腫の可能性が示唆された。

以上の諸検査より, 盲腸原発悪性リンパ尰を疑い, 開腹手術を施行した。

手術所見：腹腔内には少量の血性腹水を認めた。肝 表面は正常であったが，腹膜および大網には，爽白色 の小結節を多数認め，悪性リンパ腫の播種と考えられ る所見を呈していた。腫瘤は回盲部に存在し，浆膜面 への浸潤が明らかであった。所属リンバ節は，転移を 思わせる拇指頭大の腫大を認めた，右半結腸切除術お よび所属リンパ節郭清術を行った（図 4 ）.

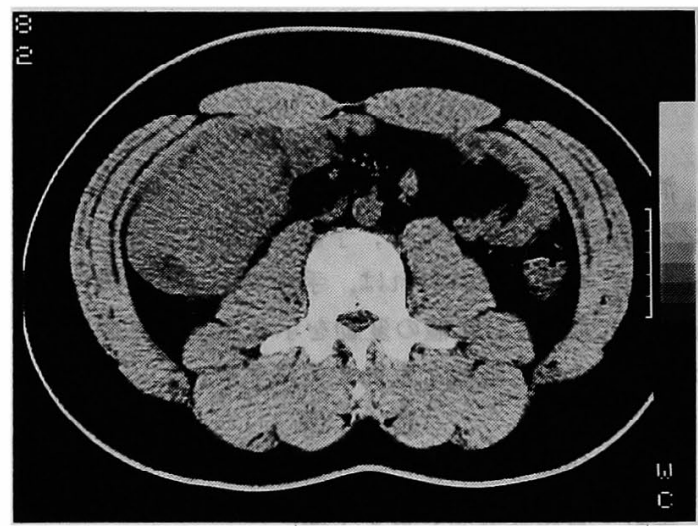

図 3 単純 CT 検査：盲腸から上行結腸にかけて, soft density mass を認める。

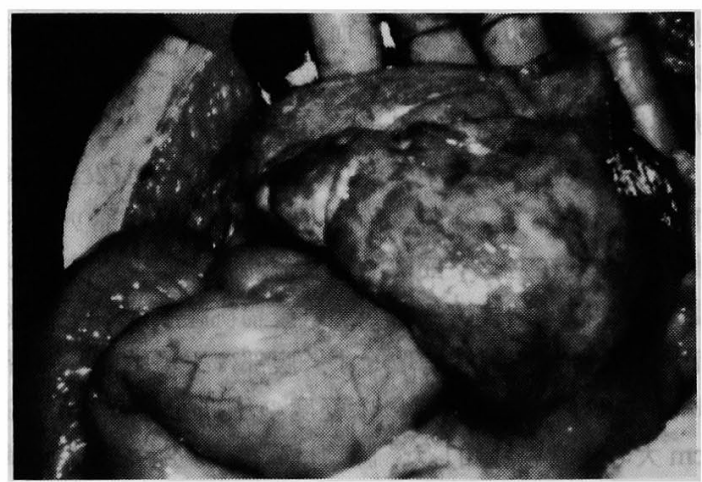

図 4 手術所見：回盲部に，浆膜浸潤する腫瘤を認め た。 
切除標本肉眼所見：腫樒は盲腸を中心とした $8.2 \times$ $8.0 \mathrm{~cm}$ 大の隆起性病変で，表面軽度凹凸不整，浅い潰 場がみられた（図 5)。

病理組織学的所見：腫場細胞は, 粘膜下層から筋層 にかけて増殖し，一部は浆膜や倸膜外脂肪組織への浸 潤も見られた，粘膜は萎縮し，浅い漬瘍を認め一部は 壊死に陥っていた。腫瘍細胞は㼛漫性に増殖し，核は 大きく類円形で，くびれを有し，核膜は繊細で，核小 体は小さい，核分裂像は散見するが，あまり顕著では ない，細胞質に乏しい，組織球を混在しながらの増殖 であり, LSG 分類の diffuse medium sized cell type の malignant lymphoma 々診断した（図 6 )。酵素抗 体法による免疫組織化学的な検討では, 腫瘍細胞は B

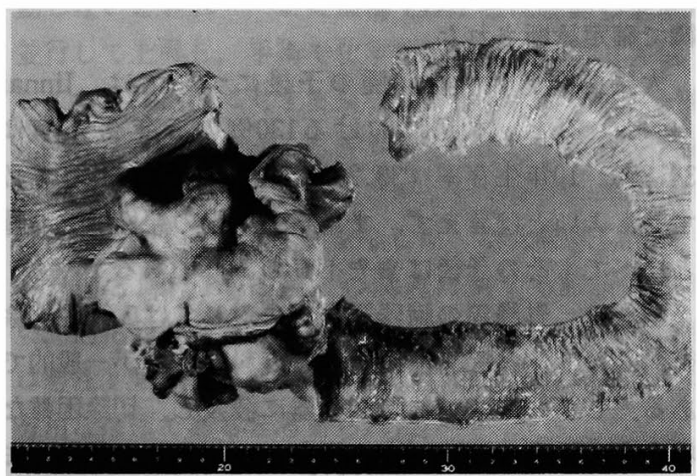

図 5 切除標本肉眼所見：甾腸を中心とした隆起性病 変がられる.
細胞のマーカーである CD20陽性で成人 $\mathrm{T}$ 細胞のマー カーである CD3陰性, IgG 陽性であり, B 細胞型の悪 性リンバ腫と考えた(图 7 ). 腹水中の組織学的検索に よっても同じく悪性腫場細胞を認めた。

術後経過：術後 2 週間目頃より腹水の増大とともに 血清 LDH 值の上昇を認めた。腹膜播種性転移および 腹水中に悪性腫瘍細胞を認めたことより, 術後15日目 にCHOP 変法3) (Adriamycin 50mmg, Vincristin 3.8 mmg, Ifosmide $400 \mathrm{mg}$, Predonin $80 \mathrm{mmg}$, 一回静注) を施行した，翌日より呕気，呕吐，尿量減少がみられ， 翌々日には無尿状態となった，血液検査で， $\mathrm{pH} 7.24$ ， BE - 15.1, BUN $105 \mathrm{mg} / \mathrm{dl}$, Cre $5.1 \mathrm{mg} / \mathrm{dl}$, K 5.2 $\mathrm{mEq} / \mathrm{L}$ となり急性腎不全と診断し，透析療法を開始

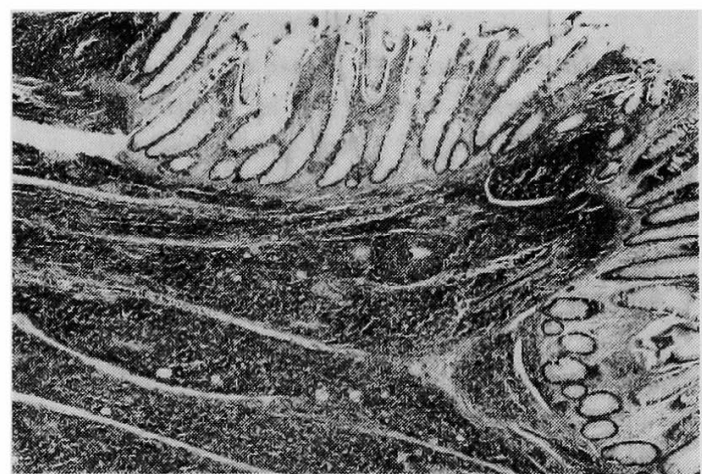

图 6 病理組織学的所見：厘瘍細胞は, 粘膜下層から 筋層にかけて，濔漫性に増殖している。
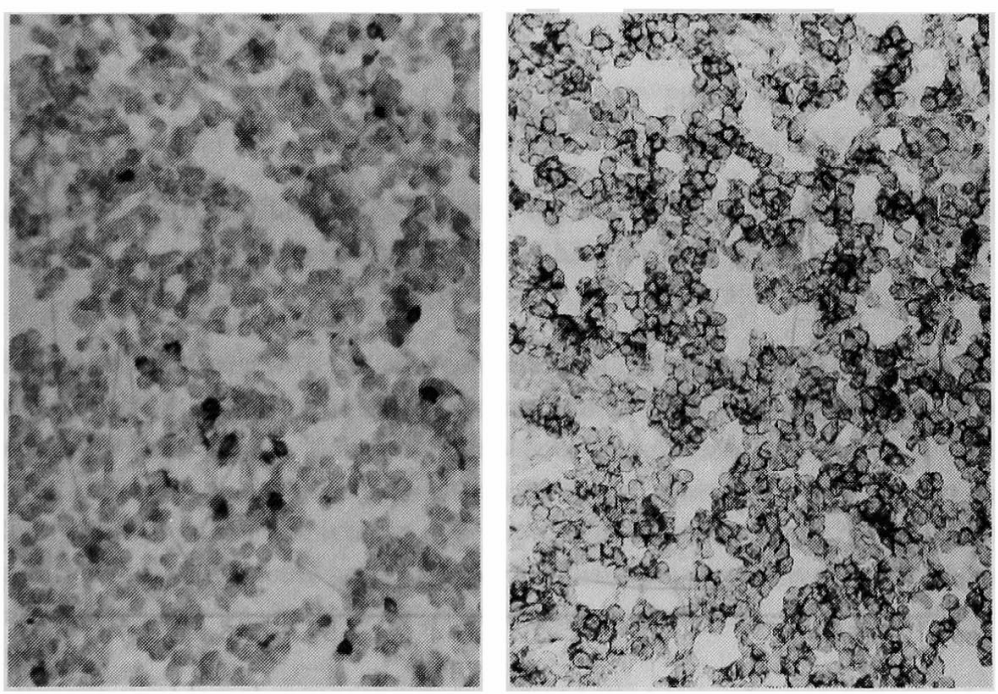

図 7 病理組織学的所見：腫瘍細胞は，CD20陽性（右）でCD3陰性（左）であった。 
した。透析は術後35日目まで計 9 回施行した。一方， 化学療法後には, 腹水量の减少㧍よび, 血清 LDH 值が $5,390 \mathrm{U}$ から正常値へと著しく低下した。透析離脱後 の経過は良好であり，術後44日目に镸院した。しかし， 術後 $6 \sim 7$ カ月後には, 血清 LDH 值が再上昇を示し, 悪性リンパ腫の再然を認めた。化学療法を行うも, 訹 後 8 カ月後に死亡した（図8，9）.

\section{考察}

消化管悪性リンパ腫の発生頻度は，全悪性リンハ腫 の10〜20\%4) とされている. 缄器別頻度については, 胃 に最も多く，次いで小腸に多く，大腸には比較的少な いと報告されている516). Jinnai $ら^{7)}$ は本邦130例の大腸

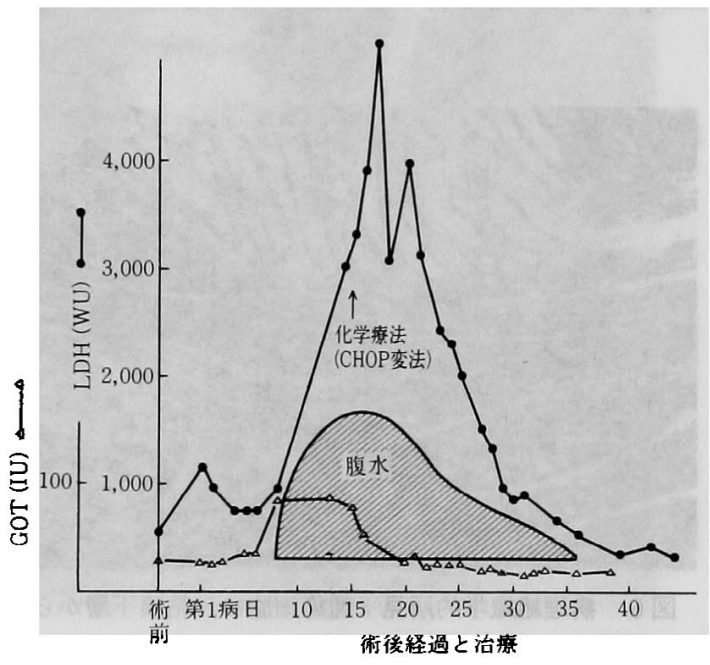

図 8 街後経過と治療
原発悪性リンパ腫の部位別発生頻度では, 盲腸 $71.5 \%$, 直腸 $16.9 \%$, 上行結腸 $6.2 \%, \mathrm{~S}$ 状結腸および肛門管が それぞれ $1.5 \%$, 虫垂, 横行結腸，下行結腸がそれぞれ $0.8 \%$ であり，盲腸の発生頻度が王倒的に高いと述へて おりり，大腸のなかでは盲腸が最もリンバ組織が発達し ているためとしている.

本症の診断に関しては, 注腸 X 線検査が重要な手段 である. 注腸 X 線上, 癌腫との鑑別について松川らら日) 悪性リンパ腫は陌凹部での辺縁が平滑であること, 進 展性がやや良好であることをあげている。しかしこれ らの所見も癌腫との決定的鑑別点とはなり難いと思わ れる. 大腸ファイバースコピーも有力な診断方法と考 えられるが, 生検診断においても, 術前確定診断が困 難なことが多い，自験例でも生検診断では悪性りンバ 腫が強く疑われたが確定にはいたらず，摘出標本の組 織で確定診断された。

大腸原発悪性リンパ腫の予後については, Jinnai ら》によると，本邦に拈ける130例の5年生存率は $34.8 \%, 10$ 年生存率は $33.2 \%$ であり, 癌腫と比べて必 ずしもよいとは言えず，また胃や小腸の悪性りンバ畽 と比へててるの予後はやや不良のよらである.

治療は, 胃腸等の搭器原発例に対しては広範用切除 術およびリンパ節郭清術を行う外科的治療が一般的で ある。しかし，すでに隣接䁍器に波及し，切除困難な 場合や，腫場の遺残がある場合には，術後の補助療法 が必要である112)．一般に，限局型には放射線療法，全 身型には，多剤併用化学療法が主流である. 自験例は, Naqvi 分類5で stage IV であり，非治瘾切除例であっ

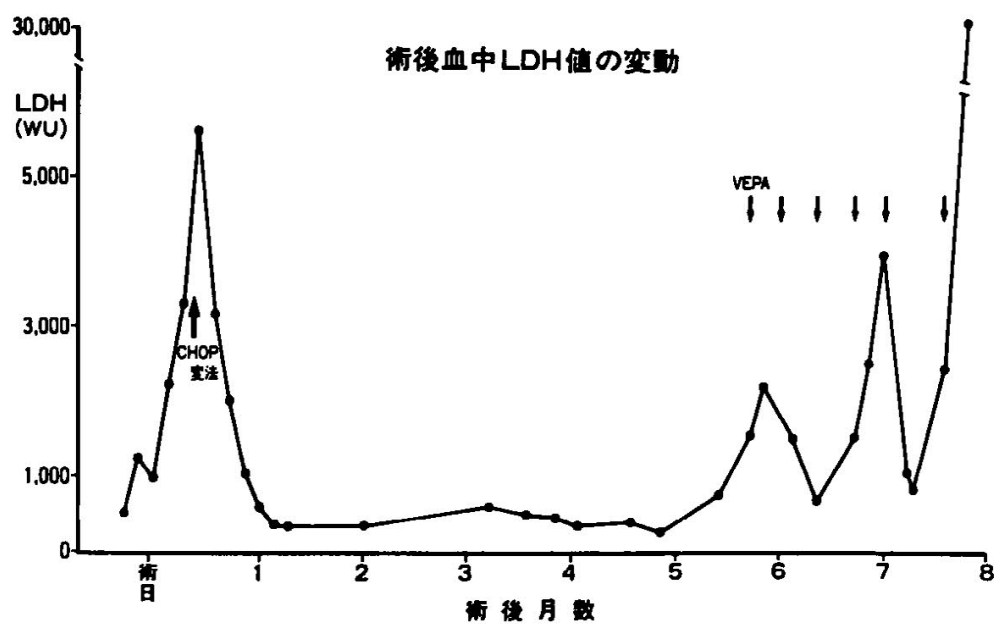

図 9 術後血清 LDH 值の変橲 
たため術後にCHOP 変法を施行した. 術後 2 週間目頃 より血清 $\mathrm{LDH}$ 值の上昇および腹水の詝留を認めてい たが，化学療法後には血清 $\mathrm{LDH}$ 值の低下と腹水の軽 減を認めた。

LDH は細胞質に多く存在する解糖系の酵素であ り，細胞破壞や変性により血中に逸脱してくるが，蔵 器特異性に乏しく種々の病熊で增加し, 多くの悪性腫 場患者でその上昇が認められる，自験例では，血清 LDH 値のフインザイムパターンが, LDH I $12.3 \%$, LDH II $35.9 \%$, LDH III $32.5 \%$, LDH IV $13.6 \%$, LDH V 5.6\% と, 分画II，III，IVの LDH の上昇が主 体であり，また術後14日目頃に，腹水の増加にともなっ て血清 LDH 値の上昇があり, 悪性りンパ属の増悪に よると考えられた旬10). 血清 LDH 值は透析療法では変 動しないとされ11), また血清 LDH 值は重湯の進展に 並行して上昇し, 手術や化学療法の奏効に応じて低下 しており，治療に対する反応性の指標になった，一般 に悪性リンバ腫では，血清 LDH，ALP，Ca 値が経過 観察上の指標になり得るとされているが12)，本症例で は血清 LDH 値のみ变動を示した。消化管原発悪性り ンパ腫と血清 LDH 値との関連に関する報告は少な い，消化管原発覀性リンパ腫に批てて血清 LDH 值 は悪性リンバ腫再燃の早期発見および治療効果判定に 有用な指標であると考劣られた。

\section{おわりに}

19歳男性, 盲腸原発悪性 リンパ腫, 特に術後血清 LDH 伯の変動をきたした 1 例を経験したので, 若干 の文献的考察を加えて報告した。

\section{文献}

1) 齋木 功, 佐藤直樹, 三沢和仁他：横行結腸原発悪 性リンパ瘇の 1 例, 日臨外医会誌 $47 ： 1496$ $-1501,1986$

2）山中達彦, 池田政宣，倉西文化他：上行結腸原発悪 性リンパ腫の 1 例, 広島医 $39: 753-757,1977$

3）木村郁朗，大歇泰亮：悪性リンパ腫，医と薬学 $17: 1421-1429,1987$

4) Gall EA, Mallory TB : Malignant lymphoma a clinicopathologic survery of 618 cases. Am J Pathol 18: 381-415, 1942

5) Naqvi MS, Burrows L, Kark AE: Lymphoma of the gastrointestinal tract. Prognostic guides based on 162 cases. Ann Surg 170: 221-231, 1969

6) Freeman C, Berg JW, Cutler SJ: Occurence and prognosis of extranodal lymphomas. Cancer $29: 252-260,1972$

7) Jinnai $D$, Iwasa $Z$, Watanuki $T$ : Malignant lymphoma of the large intestine-operative results in Japan. Jpn J Surg $13: 331-336,1983$

8）松川正明, 佐々木淳, 碓井芳樹他：大腸悪性リンパ 重のX 線診断, 胃之腸 $23: 1347-1356,1988$

9）野本昭三：乳酸脱木素酵素(LDH) 打よびLDH フ インェンザイム。金井正光 編, 臨床検査法提要, 金原出版，東京，1983，p523-529

10）五味邦英，千住 紀，高木 康：臨床化学検查診 断, 第 1 版, 宇宙堂八木書店, 東京, 1984, p107-113

11）太田和夫：人工腎臓の実際. 第 2 版, 南江堂, 東京, 1977, p153-170

12）尾山淳, 太田和雄：予後を左右する因子. 安部正 和, 尾前照雄, 河合忠一, 他編, 内科 Mook, 悪性 リンパ腫，金原出版，東京，1982，p207-214

\title{
A CASE REPORT OF MALIGNANT LYMPHOMA OF THE CECUM WITH ELEVATED LEVELS OF SERUM LACTIC DEHYDROGENASE
}

\author{
Masakazu YASHIRO, Hideki NISHIWAKI, Masahiro OKUNO, Yasuhisa FUJIMOTO, \\ Naoyuki TAENAKA and Kaoru UMEYAMA
}

First Department of Surgery, Osaka City University, Medical School

A 19-year-old male was admitted with the chief complaints of right lateral abdominal pain and melena. A man's fist sized mass was palpable at the right lateral abdominal region. Barium enema and fiberscopic examination of the colon revealed an ileocecal tumor. Malignant lymphoma was doubted based on the endoscopic biopsy and Garium scintigram. Laparatomy findings showed the ileocecal mass of $8 \times 8 \mathrm{~cm}$ in size and peritoneal dissemination. Right hemicolectomy and lympho node dissection were carried out. Ascitic fluid accumulated in a few days after operation, due to the acute aggravation of the disseminated malignant lymphoma with an elevated level of LDH. Acute renal failure was induced by chemotherapy with CHOP, which followed by decreases in LDH level and ascitic fluid.

A case of malignant cecal lymphoma with a response of LDH levels after operation and chemotherapy, was reported. 